\title{
Growth Performance and Apparent Nutrient Digestibility Coefficients of Weaned Rabbits Fed Diets Containing Different Forms of Cocoa Pod Husk Meal
}

\author{
P. O. Ozung ${ }^{1} \rtimes$ \\ O. O. Kennedy Oko² \\ E. A. Agiang ${ }^{3}$ \\ P. O. Eburu ${ }^{4}$ \\ E. I. $\operatorname{Evans}^{5}$ \\ C. E. Ewa ${ }^{6}$
}

1,2,s, Department of Animal Science, University of Calabar, Calabar, Nigeria

${ }^{5}$ Department of Animal Science, Akwa Ibom State University, Obio Akpa Campus, Uyo, Nigeria

${ }^{6}$ Department of Animal Breeding \& Physiology, Michael Okpara University of Agriculture, Umudike, Abia State, Nigeria

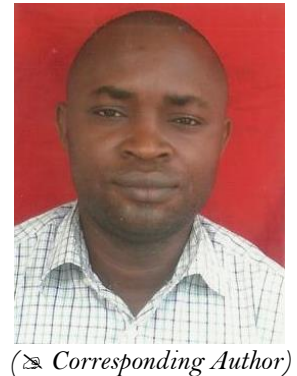

\begin{abstract}
The growth performance and apparent nutrient digestibility co - efficients of weaned rabbits fed corn - soybean meal basal diets containing different forms of cocoa pod husk meal were determined. A total of 60 mixed breed rabbits of both sexes (30 bucks and 30 does) with average initial weight of $606.42 \pm 1.30 \mathrm{~g}$ were used in a nine week feeding trial using a completely randomized design. Twelve is nitrogenous and is caloric diets were formulated containing sundried (T1 T2, T3 \& T4), fermented (T5 T6, T7 \& T8), and hot - water treated (T9 T10, T11 $\&$ T12) cocoa pod husk meal (CPHM) each at $0,12.5,25$ and $37.5 \%$ levels of inclusion, respectively. Diet with $0 \%$ CPHM served as the control in the different forms of the cocoa pod husk meal based diets. Growth performance parameters (feed intake, weight gain and feed conversion ratio) were determined, while apparent nutrient digestibility coefficients were determined at the 9th week using the direct in vivo method. The digestibility co - efficients were calculated using appropriate formula. Results of the study revealed that the final weight, total weight gain and average daily feed intake recorded significant $(\mathrm{P}<0.05)$ differences between dietary treatments. When compared with values in the control, diets with the highest inclusion level $(37.5 \%)$ CPHM had the least total weight gain with the sundried, fermented and hot - water treated groups having $557.50,570.83$ and $390.00 \mathrm{~g} /$ rabbit respectively. The average daily feed intake declined with increasing levels of sundried CPHM (i.e. 66.94, 62.56, 59.27 and 52.98 $\mathrm{g} / \mathrm{rabbit} /$ day, respectively). The hot - water treated CPHM diets recorded the worst FCR beyond $12.5 \%$ level when compared with other forms of CPHM. Some of the apparent nutrient digestibility coefficients for ash and NFE recorded significant $(\mathrm{P}<0.05)$ differences between dietary treatments, while crude protein, crude fibre and ether extract digestibility coefficients were statistically similar across dietary treatments in all the three forms of CPHM. The sundried CPHM had the least digestible crude protein $(75.07 \%)$ at the highest inclusion level $(37.5 \%)$. The study concludes that the three different forms of cocoa pod husk meal in the following order of superiority (fermented, hot - water treated and sundried) can be included in diets meant for rabbits at levels not exceeding $25 \%$ for optimum growth performance and apparent nutrient digestibility co - efficients.
\end{abstract}

Keywords: Growth, Digestibility, Rabbits, Cocoa

Citation | P. O. Ozung; O. O. Kennedy Oko; E. A. Agiang; P. O. Eburu; E. I. Evans; C. E. Ewa (2017). Growth Performance and Apparent Nutrient Digestibility Co - Efficients of Weaned Rabbits Fed Diets Containing Different Forms of Cocoa Pod Husk Meal. Agriculture and Food Sciences Research, 4(1): 8-19. History:

Received: 19 April 2017

Revised: 8 June 201

Accepted: 14 June 2017

Published: 20 June 2017

Licensed: This work is licensed under a Creative Commons Attribution 3.0 License $(\mathrm{cc})$ E

Publisher: Asian Online Journal Publishing Group
Contribution/Acknowledgement: All authors contributed to the conception and design of the study.

Funding: This study received no specific financial support.

Competing Interests: The authors declare that they have no conflict of interests.

Transparency: The authors confirm that the manuscript is an honest, accurate, and transparent account of the study was reported; that no vital features of the study have been omitted; and that any discrepancies from the study as planned have been explained.

Ethical: This study follows all ethical practices during writing. 


\section{Contents}

1. Introduction

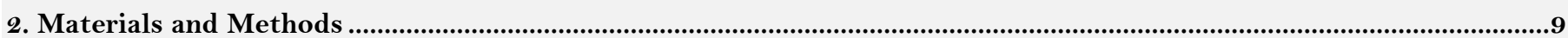

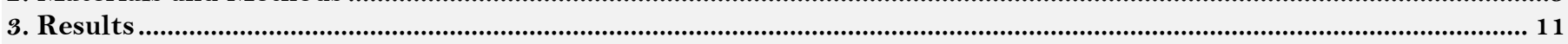

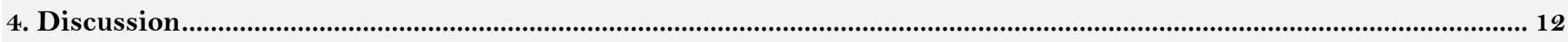

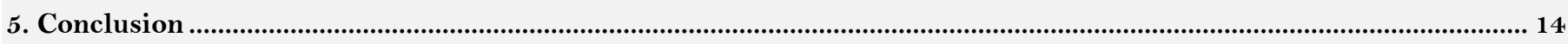

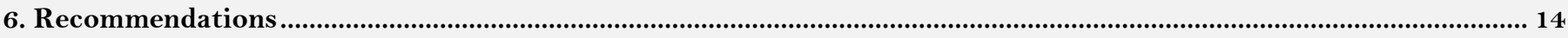

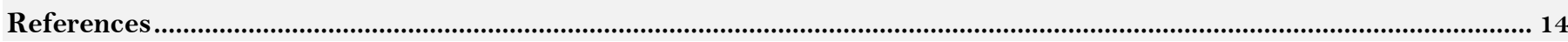

\section{Introduction}

Extant records show that livestock husbandry occupies about 30 percent of the total arable land in the world [1]. But with the rapid exhaustion of limited animal products, increasing population and better life styles, it is now imperative to explore other aspects of livestock production to bridge the gap of protein intake from animal origin. According to $\mathrm{FAO}$ [2] from year 2000 to 2020 , the projected world requirement for animal protein would increase tremendously due to population explosion. Traditionally, ruminants and monogastrics (poultry and pigs) are the main sources of domestic meat. However, rabbits and other micro livestock species (grasscutters, snails and quails) are emerging in many developing countries like Nigeria as potential sources of animal protein. The inadequacy of animal protein coupled with stiff competition between man and animals for agricultural produce call for enhancing the diversification and productivity of livestock and this has culminated in resurgence of interest in rabbit production [3]. The renewed interest in rabbit production by researchers and farmers in Nigeria has necessitated research into alternative feed resources that are readily available, under - utilized agro by - products or agro industrial wastes to substitute or supplement the highly demanded conventional cereals [4].

A major aspect of livestock production that constitutes huge cost and demands urgent attention is the utilization of quality animal feeds. The quest for non - conventional feed resources is imperative, due to the competitive pressure on grains and conventional seed meals which have outweighed production [5]. The immediate challenge therefore is for Animal Scientists/ researchers and feed mill operators to promote the utilization of cheap and affordable alternative feed resources that are rich in nutrients and are well adapted to tropical climatic conditions [2]. Literature reports abound on the use of agro - industrial by - products and farm waste materials in livestock nutrition. They include wheat and rice offals as well as maize bran and brewers dried grains (BDG) or yeast. According to Atteh and Opawande [6] BDG can replace groundnut cake in diets meant for finishing - broilers. Rice milling wastes have been utilized in diets meant for cockerel finishers [7] while Afolayan [8] utilized corn bran meal at different levels in broiler chicken diets. However, the prices of most of these by products have escalated as a result of high demand; thereby necessitating the quest for cheaper alternatives. There is the need to include alternative feedstuffs common in the tropics in rabbit diets, for the purposes of promoting optimum performance characteristics and reduction in cost of production and to make rabbit farming profit oriented to the teaming unemployed youth and rural poor farmers in Nigeria [9].

The domestic rabbit is a pseudo - ruminant (monogastric - herbivore or hind gut fermentor) that feeds on forages, grains/ concentrates and hay [10]. Most diets for rabbits consist of ingredients from plant sources [1113] composite mixture of table scraps [14] and agro by - products [15-17]. One of the promising agro by products that can be utilized in rabbit diet formulations is the cocoa pod husk. According to Olubamiwa and Akinwale [18] cocoa pod husk meal (CPHM) can partially replace maize in layers diet at 25 percent level with no adverse effects on egg parameters. Untreated CPHM has been added in the diets of growing swine up to $300 \mathrm{~g} / \mathrm{Kg}$ without deleterious signs on body characteristics [19]. The practice of incorporating cocoa pod husk meal in various animal diets has been reported [13, 20-25]. Accordingly, Smith, et al. [26] reported that sun- dried cocoa beans contain 0.70 percent sugar, 0.70 percent starch, 1.70 percent theobromine (an alkaloid), 6.70 percent protein and $50-55$ percent pale yellow, non - drying fat known as cocoa butter. The cocoa bean testa has been used successfully in feeding trials for small ruminants without adverse effects on performance characteristics [27]. Cocoa pod husks constitute 75 percent of the entire cocoa fruit on fresh weight basis Fagbenro [28]. Adomako [29] reported that cocoa beans account for less than 2.55 percent of the whole fruit. According to Donkor, et al. [22] cocoa pod husks contain $6-7$ percent crude protein, 9 - 10 percent total ash, $1-8$ percent crude fat (ether extract) and 23 - 33 percent crude fibre. Also findings by Ozung, et al. [13] showed that cocoa pod husk meal has between 7.70 and 9.37 percent crude protein, ether extract $(8.83-11.68 \%)$ and ash $(9.30-10.85 \%)$. Sobamiwa and Longe [30] reported that metabolizable energy of cocoa pod husk is moderate and ranges from $2000-2100$ $\mathrm{Kcal} / \mathrm{Kg}$; which is comparable to that of palm kernel cake, soybean meal, rice bran and brewers dried grain [31]. The processed cocoa pod husks have been reported to have low theobromine content. The crude fibre is easily digestible [32]. It is reported that cocoa pod husk is digestible by all classes of livestock, especially ruminants. However, the high crude fibre content $(21.49-34.82$ percent) hinders its effective utilization by monogastrics [33]. This constraint calls for the processing of the cocoa pod husks by various methods (fermentation, hot - water treatment, urea, enzyme, fungal treatment and microbial detheobromination), so as to promote digestibility and biodegradability in animals. Other researchers have carried out nutritional and growth performance studies with cocoa pod husk meal on poultry and small ruminants, but there is paucity of research findings on the effect of sundried, fermented and hot - water treated cocoa pod husk meal on the growth performance and apparent nutrient digestibility co - efficients of rabbits, hence the objectives of this study.

\section{Materials and Methods}

\subsection{Location of the Study}

The study was carried out at the Rabbitry Unit of the Teaching and Research Farm, Department of Animal Science, University of Calabar, Calabar, Cross River State, Nigeria. According to the GeoNames geographical database, Calabar is located at $4.9517^{\circ}$ latitude and $8.322^{\circ}$ longitude (in decimal degrees) with an average elevation/ altitude of 42 metres [34]. While, Akpan, et al. [35] reported that Calabar is located at latitude $3^{\circ} \mathrm{N}$ and longitude $7^{\circ} \mathrm{E}$, with a land mass of 233.2 sq. miles $\left(604 \mathrm{~km}^{2}\right)$. The annual rainfall ranges from $3000-3500 \mathrm{~mm}$ 
(average of $1,830 \mathrm{~mm}$ ) per annum and the average daily temperature is $25^{\circ} \mathrm{C} / 77^{\circ} \mathrm{F}$ which increases to $30^{\circ} \mathrm{C}\left(86^{\circ} \mathrm{F}\right)$ in August. The relative humidity is between $70-80$ percent.

\subsection{Collection, Processing and Proximate Analysis of Cocoa Pod Husk meal (CPHM)}

Freshly broken composite cocoa pod husks (derived from improved/hybrid cocoa varieties - CRINc1 - 8, WACRI 11 Hybrids and F3 - Amazon) were obtained from the fermentation units of the Cocoa Research Institute of Nigeria (CRIN) sub - station at Ajassor, Ikom LGA of Cross River State. The broken pods were washed and sun - dried for two weeks, bulked and milled with hammer mill to produce Cocoa Pod Husk Meal (CPHM) [36]. The resultant meal was shared into three (3) portions: The sundried CPHM (SCPHM), Fermented CPHM (FCPHM) and Hot water - treated CPHM (HCPHM), respectively. CPHM for the fermented treatment was thoroughly mixed with 60 percent water, relative to its weight as ascertained by Bello, et al. [37] and bagged using an air tight polythene bag. This was allowed to stay for three (3) days under room temperature, thereafter, it was opened and shade dried for five (5) days; before being packed, bagged and stored in a cool dry place until it was used. The final portion of CPHM was treated with hot water that was boiled to $100^{\circ} \mathrm{C}$ for 15 minutes [38-40] which was later drained, shade dried and stored for later use.

\subsection{Experimental Diets}

Twelve (12) experimental isonitrogenous and isocaloric diets for the growth phase were formulated in line with the nutrient needs of rabbits as recommended by Aduku and Olukosi [10]. Each processed form of CPHM was included at $0,12.50,25.00$ and 37.50 percent levels for $\mathrm{T}_{1}, \mathrm{~T}_{2}, \mathrm{~T}_{3}$, and $\mathrm{T}_{4}$ (Sundried CPHM), $\mathrm{T}_{5}, \mathrm{~T}_{6}, \mathrm{~T}_{7}, \mathrm{~T}_{8}$ (Fermented CPHM) and $\mathrm{T}_{9}, \mathrm{~T}_{10}, \mathrm{~T}_{11}, \mathrm{~T}_{12}$ (Hot - water treated CPHM), respectively in the experimental diets. Diet without CPHM (O percent) served as control in the experiment. The choice of these levels was based on earlier reports on the use of much lower levels of CPHM for poultry, pigs and rabbits without adverse and significant effects on growth performance characteristics [36, 39, 40]. Feedstuff purchase/choice and procurement of cocoa pod husks as well as methods of processing CPHM and ration formulation gave primary consideration to least cost and maximum biological returns [41]. The proximate composition of the experimental diets was done based on the procedures outlined by A.O. A.C $\left[42^{2}\right]$. The gross composition of experimental diets is presented in Table 1.

\subsection{Experimental Rabbits and Management}

Sixty (60) weaned mixed breed rabbits (Chinchilla X New Zealand X Californian) between 5 and 6 weeks old of both sexes (30 bucks and 30 does), (average initial body weight of $606.42 \pm 1.30$ ) ) were used in this study. The rabbits were purchased from a reputable rabbitry (Domino farms, Use - Offot) in Uyo, Akwa Ibom State. They were managed based on standard experimental procedures. On arrival at the rabbitry facility, the animals were provided with anti - stress vitalyte (Anidone - vita dox) at $0.50 \mathrm{~g}$ per 75 litres of chlorine - free water. Concrete drinking troughs and fabricated feeding troughs (empty beverage cans nailed to the wooden board) were provided in each cage. The rabbits adjusted for two weeks before the actual commencement of the feeding trial and within this period; they were placed on commercial pelleted grower mash and given prophylactic treatment against bacterial and viral infections using a broad spectrum antibiotic - Oxytetracycline hydrochloride eq.50mg (soluble powder - 5 percent $\mathrm{w} / \mathrm{w}$ ) at recommended dosage of one teaspoonful per 4 litres of chlorine - free water. The animals were thereafter screened against ecto and endo parasites via subcutaneous injection of Ivermectin (Kepromec) at the recommended level (0.20 ml per rabbit). Thereafter, the animals were subjected to nine (9) weeks (63 days) initial feeding trial during which their pre - pubertal growth performance characteristics and apparent nutrient digestibility co -efficients were evaluated.

\subsection{Housing and Equipment}

The experimental animals were accommodated individually in double tier wooden hutches (with wire mesh floor) measuring $65 \times 65 \times 65 \mathrm{~cm}(\mathrm{~L} \times \mathrm{H} \times \mathrm{W})$ and raised $25 \mathrm{~cm}$ from the ground and placed in a standard rabbitry with half walls to allow for cross ventilation.

\subsection{Experimental Design}

Animals were randomly distributed to the test diets using a simple Completely Randomized Design (CRD) with three processed forms of CPHM. They were twelve (12) dietary treatments with five (5) rabbits per treatment (each rabbit served as a replicate). The rabbits were assigned to the various treatments after equalizing for body weights.

\subsection{Feeding of Animals/ Feed Intake}

Respective rabbits were given weighed amount of feed weight daily in the morning hours (07:00 - 08:00 am) and adjusted weekly to make provision for the weekly weight change, while water was given without restriction. The left over feed samples were collected into marked envelopes and weighed daily with a precision electronic balance; model HK - DC-320AS with minimum and maximum sensitivities of 0.01 and 320g, respectively. The feed intake was computed by difference. Fresh Aspilia africana leaves (supplementary forage) were harvested daily, air dried and fed to the rabbits in the evening period (17:00 - 18:00 hours) at a uniform amount of $30 \mathrm{~g}$ in all the treatments.

\subsection{Weighing of Animals}

At the beginning of the trial, the rabbits were weighed individually and thereafter on a weekly basis. Body weight changes were determined by difference. A top loader weighing scale was used in determining the weight changes of rabbits.

\subsection{Feed Conversion Ratio}

The feed conversion ratio was determined as the ratio of feed consumed $(\mathrm{g})$ to weight gain $(\mathrm{g})$. 


\subsection{Digestibility Trial}

Digestibility is an important measure of the nutritive value of feedstuffs. It is the difference in value between the feed eaten and materials voided by the animals expressed as percentage of feed eaten [43]. A direct method (in vivo) involving feeding experiment with rabbits was used in this study [44]. The digestibility trial was carried out at the ninth week and lasted for 15 days, using thirty six rabbits (i.e.3 rabbits) per treatment. No faeces were collected for the first 7 days, but faecal material and feed intake were recorded for the last 8 days. Faecal samples collected from each day were oven - dried at $60^{\circ} \mathrm{C}$, preserved in bags and stored in a refrigerator. At the end, all faecal samples collected from each replicate were pooled together for the determination of proximate composition using the A.O. A.C [42] methods. Percentage digestibility of diets was obtained as follows:

Percent Digestibility $=$ Quantity in feed - Quantity in faeces

$\times 100$

\subsection{Statistical Analysis}

Quantity in feed

Data obtained in this study were subjected to one - way Analysis of Variance (ANOVA) using General Linear Model [45] for a completely randomized design (CRD) of GenStat Release 10.3DE (2011). Significant means were separated using Least Significance Difference (LSD) option [46] of the same statistical software.

The model used was as follows:

$\mathrm{Y}_{\mathrm{ij}}=\mu+\mathrm{T}_{\mathrm{i}}+\mathrm{E}_{\mathrm{ij}}$

Where:

$\mathrm{Y}_{\mathrm{ij}}$ : Observed value

$\mu$ : Overall (population) mean value

$\mathrm{T}_{\mathrm{i}}$ : Random effect of the $\mathrm{i}^{\text {th }}$ processing method of CPHM

$\mathrm{E}_{\mathrm{ij}}$ : Random residual error

\section{Results}

\subsection{Proximate Composition (Determined Analysis) of Experimental Diets, Test Ingredient (Cocoa Pod Husk Meal) and Fibre Fractions}

Results of the proximate composition of the diets (Growth phase) are presented in Table 2. The proximate fractions $(\mathrm{CP}, \mathrm{CF}, \mathrm{EE}, \mathrm{Ash}$ and NFE) recorded significant differences $(\mathrm{P}<0.05)$ between dietary treatments. The control diet (O percent CPHM) recorded the highest crude protein $(\mathrm{CP})$ (18.30 percent) content while the least value was recorded in the raw cocoa pod husk meal (CPHM) with 37.50 percent as 14.04 percent. The crude fibre content increases as the level of CPHM inclusion increased across the diets, highest values were recorded in the 37.50 percent inclusion level with 23.53, 26.37 and 23.08 percent respectively for the raw, fermented and hot water treated CPHM. While the proximate composition and fibre fractions of the raw, fermented and hot - water treated CPHM are summarised in Table 3. All parameters, except the total digestible nutrients (TDN) had significant differences $(\mathrm{P}<0.05)$ between processing methods of $\mathrm{CPHM}$. The $\mathrm{CP}$ values were 9.37, 7.70 and 8.94 percent for the raw, fermented and hot - water treated CPHM, respectively. The raw CPHM recorded the highest CF content (61.80 percent), followed by the fermented CPHM (57.42 percent) and the least value was recorded in the hot - water treated CPHM (53.37 percent). The trend was however reversed for other fractions like ether extract (EE), ash and Nitrogen free extract (NFE) contents as the highest values were recorded in the hot - water treated CPHM, followed by the fermented CPHM and least in the raw CPHM. The EE values were 8.83, 9.52 and 11.68 percent while the values for ash content were 9.30, 10.80 and 10.85 percent and NFE values were 10.70, 14.56 and 15.16 percent respectively, for raw, fermented and hot - water groups. The Acid detergent fibre (ADF) and Neutral detergent fibre (NDF) values were highest in the fermented CPHM (73.09 and 79.45 percent, respectively), followed by the raw CPHM (68.64 and 75.08 percent, respectively) and least in the hot - water treated CPHM (64.60 and 71.09 percent, respectively).

\subsection{Growth Performance Characteristics of Rabbits}

Results of the pre - pubertal growth performance attributes of weaned rabbits fed cocoa pod husk meal based diets are summarised in Table 4. The final weight, total weight gain and average daily feed intake (ADF) of rabbits recorded significant differences $(\mathrm{P}<0.05)$ between dietary treatments. The total weight gain recorded highest values in the respective control diets for the raw $(1048.00 \mathrm{~g} / \mathrm{rabbit})$, fermented $(907.50 \mathrm{~g} / \mathrm{rabbit})$ and hot - water treated $(710.00 \mathrm{~g} / \mathrm{rabbit})$ CPHM. Dietary treatments with the highest inclusion level (37.50 percent) of CPHM recorded the least values of total weight gain, with the raw, fermented and hot - water treated forms of CPHM having 557.50, 570.83 and $390.00 \mathrm{~g} / \mathrm{rabbit}$, respectively. Results further revealed that the fermented and raw CPHM recorded better total weight gain across dietary treatments compared to the hot - water treated CPHM (which recorded the least total weight gain) in this study. Average daily gain (ADG) values for the raw CPHM were $16.63,10.95,13.84$ and $8.85 \mathrm{~g} / \mathrm{rabbit} /$ day in the control, 12.50, 25.00 and 37.50 percent inclusion levels, respectively. The fermented CPHM recorded ADG values of 14.40, 10.42, 13.85 and 9.06g/rabbit/day in $0,12.50$, 25.00 and 37.50 percent levels, respectively. While the hot - water treated CPHM recorded ADG values of 11.27, $10.13,6.24$ and $6.19 \mathrm{~g} / \mathrm{rabbit} /$ day, respectively for $0,12.50,25.00$ and 37.50 percent inclusion levels. The average daily feed intake (ADF) of rabbits declined with increasing levels of raw CPHM in the dietary treatments. The values were 66.94, 62.56, 59.27 and $52.98 \mathrm{~g} / \mathrm{rabbit} /$ day in the control, $12.50,25.00$ and 37.50 percent inclusion levels, respectively. The fermented and hot - water treated CPHM however recorded higher values of ADF compared to the raw CPHM. The hot - water treated CPHM recorded the highest and worst values of feed conversion ratio (FCR), compared with the two other forms of CPHM and the control diets. 


\subsection{Apparent Nutrient Digestibility Co - Efficients}

Results of nutrient digestibility co - efficients of rabbits fed diets containing cocoa pod husk meal are presented in Table 5. Digestibility parameters like ash and NFE recorded significant effect $(\mathrm{P}<0.05)$ of dietary treatments, while the values for dry matter, crude protein, crude fibre and ether extract were statistically similar. In the raw CPHM, the highest inclusion level of 37.50 percent recorded the least digestibility value of 75.07 percent for crude protein $(\mathrm{CP})$ compared to the control diet and other lower levels of inclusion. The trend was however reversed in the fermented and hot - water treated CPHM as the highest digestibilty values for $\mathrm{CP}$ were recorded in the 37.50 percent inclusion level as 78.11 and 77.74 percent, respectively. The digestibility values for crude fibre (CF) were 77.92, 78.44, 75.05 and 74.50 percent for $0,12.50,25.00$ and 37.50 percent, respectively in the raw CPHM; while the fermented CPHM recorded digestible $\mathrm{CF}$ values of 76.79, 71.03, 61.14 and 76.68 percent for $0,12.50,25.00$ and 37.50 percent, respectively; the hot - water treated CPHM had 77.42, 85.97, 80.80 and 82.19 percent, respectively for $0,12.50,25.00$ and 37.50 percent inclusion levels.

\section{Discussion}

\subsection{Determined (Proximate) Composition of Experimental Diets, Cocoa Pod Husk Meal and Fibre Fractions}

The proximate composition values of experimental diets in this study (Table 2) are within the recommended ranges for growing rabbits. The crude protein content of diets $(14.04-18.73$ percent $)$ falls within the recommended levels $(16-18$ percent) for both growing and breeding rabbits [47-51]. Rabbits have been observed to adapt effectively to low and poor protein diets unlike poultry, because of coprophagy [52]. However, crude protein levels of 12,15, 16 and 17 percent have been reported as optimum for rabbits in terms of maintenance, gestation, growth and lactation, respectively $[10,53]$. The crude protein content in this study proved satisfactory, as the rabbits recorded effective growth and reproductive efficiency. The crude fibre content (13.38 - 26.37 percent) of the experimental diets was higher than the recommended level $(10-14$ percent) for rabbits [54] but within the range $(22.96-32.06$ percent $)$ reported by Ijaiya, et al. [15]. The high crude fibre levels were apparently due to the high crude fibre content of the test ingredient (cocoa pod husk meal) used in this study. According to Champ and Maurice [55] a crude fibre level in excess of 9 percent is needed for normal growth in rabbits and to reduce incidence of enteritis; while a high fibre level in excess of 20 percent may induce caecal impaction and limit energy intake [10]. However, rabbits fed higher levels of fibre in this study did not show any obvious adverse effect. Furthermore, Cheeke [56] reported that crude fibre levels of between 10 to 17 percent have been found to support weight gain; with the optimum gain of $41.30 \mathrm{~g} / \mathrm{day} / \mathrm{rabbit}$ obtained at a fibre level of 14.80 percent. Accordingly, satisfactory performance has been recorded in weaner rabbits fed high fibre $(22.96-32.06$ percent $)$ and high energy $(3,523.54-3,897.46 \mathrm{Kcal} / \mathrm{kg} \mathrm{ME})$ diets [15]. The energy content of the experimental diets ranges from 2,500.75 - 2,536.90 Kcal $/ \mathrm{kg} \mathrm{ME}$. The energy content was within the recommended level $(2,500-2,600 \mathrm{Kcal} / \mathrm{kg}$ $\mathrm{ME})$ for growing and breeding rabbits $[10,48,57]$.

The proximate composition and fibre fractions of the raw, fermented and hot - water treated cocoa pod husk meal (Table 3) recorded significant effect $(\mathrm{P}<0.05)$. The dry matter content in the raw cocoa pod husk meal $(94.60$ percent) was almost similar to the value (94.18 percent) reported by Onifade, et al. [53] for the raw untreated form. The dry matter values for the fermented cocoa pod husk meal (84.40 percent) and hot - water treated cocoa pod husk meal (85.28 percent) are slightly lower than the value (88.96 percent) for processed forms of cocoa pod husk meal reported by Alamowor, et al. [58]. The raw cocoa pod husk meal recorded highest values in dry matter, crude protein and crude fibre, followed by the hot - water treated cocoa pod husk meal. The fermented cocoa pod husk meal recorded the least values in dry matter and crude protein contents. The ether extract, ash, nitrogen free extract and fibre fractions were within the values reported by Marcel, et al. [59] for cocoa pod husk meal. The ash content of the raw (9.30 percent), fermented (10.80 percent) and hot - water treated (10.85 percent) cocoa pod husk meal, respectively were slightly higher than the value of 9.07 percent reported by Alamowor, et al. [58] and lower than the value of 11.14 percent reported by Onifade, et al. [53] for unprocessed cocoa pod husk meal. The proximate fractions obtained in this study are comparable to those reported by Hamzat and Adeola [60] for dry matter and ash contents of cocoa pod husk, but fairly higher in crude protein, crude fibre, acid detergent fibre, neutral detergent fibre and total digestible nutrients. The differences in values could be attributed to the different processing methods adopted in the separate studies. Nutritionally, the results revealed that cocoa pod husk meal (irrespective of the processing method) is low in nutrient contents (especially crude protein), but high in crude fibre. This is in agreement with the findings of Oddoye, et al. [19] who reported that cocoa pod husk is not too nutritious, due to its low metabolizable energy, crude protein and high crude fibre contents.

\subsection{Growth Performance Characteristics}

The growth performance characteristics of rabbits (Table 4) recorded significant differences across treatments in the final weight gain (FWG), average daily feed intake (ADF) and total weight gain (TWG). The average daily weight gain $(\mathrm{ADG})$ and feed conversion ratio $(\mathrm{FCR})$ recorded statistically similar results across dietary treatments. The ADF decreased significantly $(\mathrm{P}<0.05)$ in the raw cocoa pod husk meal group from $66.94 \mathrm{~g} / \mathrm{rabbit} /$ day in the control diet to $52.98 \mathrm{~g} / \mathrm{rabbit} /$ day in the diet with 37.50 percent of raw cocoa pod husk meal, implying the rabbits consumed more feed in the control diet. The ADF in the fermented cocoa pod husk meal decreased marginally from 66.47 to $62.75 \mathrm{~g} / \mathrm{rabbit} /$ day across dietary treatments; while the hot - water treated cocoa pod husk meal recorded a progressive trend in ADF ranging from 64.34-71.16 g/rabbit/day in dietary treatments. The values for ADF obtained in this study are comparable to the range of $63.46-70.46 \mathrm{~g} / \mathrm{rabbit} /$ day reported by Isika, et al. [61] who evaluated the replacement value of processed cocoa bean meal for groundnut cake in rations for fryer rabbits. However, the ADF values are far higher than the range of $24.08-37.16 \mathrm{~g} / \mathrm{rabbit} /$ day reported by Ahaotu, et al. [62] in Dutch rabbits fed processed ripe banana peel meal. The differences in ADF values could be attributed to age disparity, differences in feed materials and environmental influences. Metabolic processes increase with age in animals, just as the feed intake to meet maintenance and performance functions [61]. The experimental rabbits in this study appeared to follow such assertion, especially in the hot - water treated cocoa pod husk meal group. The 
feed intake in this group increased as the fibre level increased across the dietary treatments. This finding agrees with the report of Onyema and Iwuala [63] who stated that the consumption of high fibre diets resulted to increase in feed intake. However, the trend was reversed in the raw cocoa pod husk meal (CPHM) group. The plausible reason for the observed depression in ADF in the raw CPHM could be the high anti- nutrient (Theobromine) content in the raw form. Theobromine has been reported to be a key anti - nutrient in cocoa products [64] its presence is reported to limit feed intake by animals and consequently, zootechnical parameters [65]. However, the ADF was significantly $(\mathrm{P}<0.05)$ highest in the hot - water treated cocoa pod husk meal group. This validates the report of Adeyina, et al. [40] who stated that feed intake and weight gain were high in rabbits fed hot - water treated cocoa bean shell up to $200 \mathrm{~g} / \mathrm{kg}$. This is so because the hot - water treatment and fermentation methods have been reported to reduce the theobromine content in cocoa by - products [40].

The values for ADG fluctuated across dietary treatments with no definite pattern. In all the processed forms of cocoa pod husk meal, the highest inclusion level (37.50 percent) recorded the least ADG, implying that CPHM and its associated theobromine and unpalatable nature adversely affected weight gain. This agrees with the findings of Marcel, et al. [59] who reported that the use of cocoa pod husk meal above certain permissible levels will depress the weight gain of animals. The feed conversion ratios obtained in this study were poor, since the values were highest in the hot - water treated cocoa pod husk meal group, compared to other processed forms. The poor feed efficiency may be attributed to the high levels of CPHM in the rabbit diets that even fermentation and hot - water treatment could not address, and this agrees with Devender [66]; Day and Dilworth [67]; Marcel, et al. [59] who have recommended low levels of CPHM and other cocoa by - products inclusion in animal diets. High intake of highly fibrous feeds by rabbits has been reported to cause reduced feed efficiency [68]. The mortality recorded may be unconnected to the diets, but due to attack by soldier ants. Therefore, it could be stated that raw CPHM depresses the performance of animals at levels exceeding 25 percent.

\subsection{Apparent Nutrient Digestibility Co - Efficients}

The apparent nutrient digestibility co - efficients in rabbits fed raw, fermented and hot - water treated cocoa pod husk meal based- diets did not record any significant difference between dietary treatments in digestible dry matter, crude protein, crude fibre and ether extract; except the digestible ash and nitrogen free extract which were significantly affected $(\mathrm{P}<0.05)$ (Table 5). The digestibility co - efficients obtained in this study were generally high in all parameters, implying that the rabbits were able to utilize nutrients in the diets for their growth. The digestibility of crude protein declined marginally across dietary treatments in the raw cocoa pod husk meal (CPHM) group, while other processed methods recorded fluctuating trend without a definite pattern. The decline in crude protein digestibilty in the raw CPHM may be associated with the theobromine content of the raw cocoa pod husk, which has been reported to limit its utilization in animals [59] and also due to the increasing level of fibre in the cocoa pod husk meal. The decline in protein digestibility confirms the result of negative influence of fibrous substances on nutrient digestibility in farm animals [69, 70]. Reduced digestibility could be attributed to the reduction in mean retention time of feed in the alimentary canal [59]. It has also been reported that increasing the concentration of cocoa by - products in diets will increase the concentration of neutral detergent fibre, acid detergent fibre and acid detergent lignin that reduce the action of digestive enzymes in the intestine [71]. The digestible crude fibre values in this study were quite high. Meffeja, et al. [72] reported that high fibre concentrations would lead to copious production of mucus which helps in protecting the lining of the digestive tract. The co - efficients of nutrient digestibilty in this study were higher than the values reported by Meffeja, et al. [72] for cocoa shell meal. This is because the food value of cocoa shell meal is lower than that of cocoa pod husk meal and because of the low digestibilty of the nutrients in cocoa shell meal; it has been recommended for animals at the finishing phase than those under rapid growth [72]. This justifies the high value of cocoa shell meal in diets meant for small ruminants and dairy cows.

The digestibility of nutrients obtained in this study for dry matter $(95.41-96.34$ percent), crude fibre $(61.14-$ 85.97 percent), ether extract $(71.51-83.57$ percent) and ash $(56.84-83.33$ percent $)$ are fairly higher than the ranges reported by Adedire, et al. [73] for digestible dry matter (63.63 - 69.37 percent), crude fibre (55.61 - 62.88 percent), ether extract $(62.14-64.15$ percent $)$ and ash $(51.75-58.05$ percent $)$ who fed crop based residues fermented with Rhizopus oligosporus to experimental rabbits. The crude protein digestibility in this study ranges from $72.18-78.54$ percent and slightly lower than the range $(80.40-88.01$ percent) recorded by Adedire, et al. [73]. The differences in nutrients digestibilty between the separate studies could be attributed to age disparity of the rabbits, different feeding materials used as test ingredients, processing methods and associated fibre levels. The trend of dry matter digestibility was statistically similar across dietary treatments and was proportional to crude fibre level in the diets especially with the degree of lignification [74] implying that the higher the fibre content of diets, the better the dry matter digestibility. This is in line with the report of Aboushour and Baraket [75] that dry matter intake and digestibility increased as dietary fibre increases. The result obtained revealed that digestible protein did not improve significantly with fermentation and hot - water treatment of cocoa pod husk meal compared with the raw group. This may be due to the insoluble fibre in the cocoa pod husk which was not effectively digested; as insoluble fibre can be further fermented in the caeca of rabbits to derive more protein and vitamins through coprophagy or caecotrophy [76]. The presentation of cocoa pod husk meal as raw, fermented and hot - water treated forms did not have any significant effect in the digestibility of dry matter, protein, fibre and ether extract. This suggests that the processing of cocoa pod husk meal in any of the three forms did not exert any stimulating effect that could have enhanced better digestibility. This observation is in tandem with the report of Adedire, et al. [73] who opined that fermentation of plant materials may not enhance nutrient digestibility. 


\section{Conclusion}

Within the present experimental conditions, this study concludes that processed cocoa pod husk meal (CPHM) could be included in diets meant for rabbits. The order of importance is the fermented CPHM, followed by the hot - water treated CPHM and lastly the raw CPHM, respectively. The fermented cocoa pod husk meal - based diets performed best compared to other forms in terms of growth performance and nutrient utilization of rabbits.

\section{Recommendations}

Based on the outcome of this study, it is therefore recommended as that:

i. Cocoa pod husk meal (CPHM) should be fermented before it can be included in diets meant for rabbits. Hence, fermentation is the best and cheapest method of detheobromination.

ii. The level of inclusion of fermented CPHM should not exceed 25.00 percent in rabbit diets.

\section{References}

[1] FAO, "Food \& agriculture organization. Livestock, a major threat to environment. Rome, Italy. Retrieved from http://web.archive.org/fao.org/news. [Accessed $02-01-15], " 2008$.

[2] FAO, "Food \& agriculture organization. Use of lesser - known plants and plant parts as animal feed resources in tropical regions by E. S. Quansah and H. P. S. Makkar. Animal Production and Health Working Paper, No. 8, Rome," 2012.

[3] O. S. Oyadeyi, O. O. Olaniyan, O. Adeosun, O. O. Olusola, and A. B. Omojola, "Performance and carcass characteristics of wean ed rabbits fed varying levels of unfermented and wood ash digested/ fermented cocoa pod husk meal (CPHM)," in Proceedings of the 36th Conference of Nigerian Society for Animal Production, 13 - 16 March, 2011, University of Abuja, Nigeria, 2011 , pp. 758 - 761.

[4] J. A. Agunbiade, O. A. Adeyemi, O. E. Fasina, B. O. Ashor- Obi, M. O. Adebanjo, and D. E. Waide, "Cassava peels and leaves in the diets of rabbits: Its effect on performance and carcass characteristics," Nigerian Journal of Animal Production, vol. 26, pp. 29 - 34, 2000.

A. F. McCalla, "World food prices: Causes and consequences," Canadian Journal of Agricultural Economics, vol. 57, pp. 23 - $34,2009$. View at Google Scholar $\mid$ View at Publisher

[6] J. O. Atteh and F. E. Opawande, "Replacement of brewers dry grain for groundnut cake I broiler finisher diets," in Proceedings of the 25th Annual Conference of the Nigerian Society for Animal Production, Umudike, Nigeria, 2000, pp. 165 - 168.

[7] R. J. Awesu, A. M. Bamgbose, O. O. Oduguwa, A. O. Fanimo, and E. B. Oguntona, "Utilization of rice milling waste in diets for cockerel finishers," in Proceedings of the 25th Annual Conference of the Nigerian Society for Animal Production, Umudike, Nigeria, 2000, pp. $201-204$.

[8] G. G. Afolayan, "Effect of single diet corn bran meal on growth performance and nutrients retention in broiler chickens," in Proceedings of the 29th Annual Conference of the Nigerian Society for Animal Production, Sokoto, Nigeria, 2004, pp. 286 - 288.

[9] C. D. Tuluen and J. P. Patrick, "Effect of duration of cooking mucuna utilis seed meal on proximate composition, level of antinutrients and performance of broiler chicken," Nigerian Journal of Animal Production, vol. 34, pp. 45 - 53, 2007. View at Google Scholar

[10] A. O. Aduku and J. O. Olukosi, Rabbit management in the tropics: Production, processing, utilization, marketing, economics, practical training, research and prospects. Abuja, FCT: Living Books GU Publication, 1990.

[11] P. O. Ozung, J. A. Ubua, M. I. Anya, E. E. Nsa, V. N. Ebegbulem, and S. E. Etim, "Evaluation of growth performance and some haematological characteristics of weaned rabbits fed pawpaw peel meal based diets in Cross River Rainforest Zone," International Journal of Science and Nature, vol. 3, pp. 784- 787, 2012.

[12] P. O. Ozung, O. O. K. Oko, and J. O. Ekpo, "Evaluation of neem (Azadirachta Indica) leaf meal on growth performance, haematological and serum biochemical characteristics of broilers," presented at the Book of Abstracts, Tropentag Conference with the Theme Agricultural Development within the Rural-Urban Continuum in Stuttgart - Hohenheim, Germany, September 17-19, 2013, ID Number - 396, 2013.

[13] P. O. Ozung, O. O. K. Oko, and E. A. Agiang, "Chemical composition of differently treated forms of cocoa POD husk meal (CPHM)," Asian Journal of Agricultural Sciences, vol. 8, pp. 5-9, 2016. View at Publisher

[14] A. A. Shueir, "Effects of feeding cabbage residue on performance in rabbits," Journal of Applied Rabbit Research, vol. 8, pp. 177 - 180, 1985 .

[15] A. T. Ijaiya, O. O. A. Fasanya, and B. A. Ayanwale, "Growth performance of weaner rabbits fed graded levels of maize and fermented cassava peel meal based diets," Journal of Sustainable Tropical Agricultural Research, vol. 14, pp. 114-117, 2005.

[16] P. O. Ozung, I. I. Bitto, and S. A. Ikurior, "Carcass yield, gut morphology, reproductive tract morphometry and some biochemical characteristics of serum in female rabbits fed cassava peel meal based diets," Continental Journal of Animal \& Veterinary Research, vol. 3, pp. $22-32,2011$. View at Google Scholar

[17] P. O. Ozung, O. O. K. Oko, and E. A. Agiang, "Effect of raw, fermented and hot - water treated cocoa pod husk meal based - diets on the reproductive tract morphometry of rabbit bucks," in Proceedings of the 4oth Annual Conference of Nigerian Society for Animal Production (NSAP), held at NAPRI / ABU Zaria, Kaduna State, Nigeria, 15th-19th March, 2015, 2015, pp. $308-311$.

[18] O. Olubamiwa and T. O. Akinwale, "Partial placement of maize with cocoa husk meals in layers mash: An on - farm experience," Journal of Food Technology in Africa, vol. 5, pp. 62 - 63, 2000. View at Google Scholar

[19] E. O. K. Oddoye, S. W. A. Rhule, Agyente - Badu, V. Anchirinah, and A. F. Owusu, "Fresh cocoa pod husk as an ingredient in the diets of growing pigs," Scientific Research and Essays, vol. 5, pp. 1141-1144, 2010. View at Google Scholar

[20] A. R. Barnes, W. K. Amega, M. Manu, and T. Rhule, "Utilization of cocoa husk meal by growing - finishing pigs," in Proceedings of 9th International Cocoa Research Conference, Lome, Togo, 1985, pp. $449-454$.

[21] D. Adomako, D. B. Okai, and E. L. K. Osafo, "Effect of different levels of cocoa pod husk on performance and carcass characteristics of finisher pigs," in Proceedings of 9th International Cocoa Research Conference, Lome, Togo, 1985, pp. 455 - 459.

[22] A. Donkor, C. C. Atuahene, B. N. Wilson, and O. Ademako, "Chemical composition of cocoa pod husk and its effect on growth and feed efficiency in broiler chicks," Animal Feed Science and Technology, vol. 35, pp. 161 - 169, 1991. View at Google Scholar |View at Publisher

[23] D. Adomako and E. Osei- Amaning, Livestock feeding trials with cocoa pod husk in Ghana vol. 13: Cocoa Research Institute of Ghana, Technical Bulletin, 1996.

[24] D. Adomako, E. Osei- Amaning, and E. G. Asante, "Compound animal feed based on cocoa pod husk," Tropical Science, vol. 39, pp. $120-123,1999$.

[25] K. Agyente - Badu and E. O. K. Oddoye, "Uses of cocoa by- products," in Proceedings of 24th Biennial Conference of Ghana Science Association, University of Ghana, Legon, 2005, pp. $115-127$.

[26] O. B. Smith, E. L. K. Osafe, and A. A. Adegbola, "Studies on the feeding value of agro- industrial by- products, strategies for improving the utilization of cocoa pod based diets by ruminants," Animal Feed Science and Technology, vol. 20, pp. 189 - $201,1988$. View at Google Scholar | View at Publisher

[27] A. O. Akinsoyinu and A. A. Adeloye, "Studies on the utilization of cocoa seed shell by sheep and goats in Nigeria," in Proceedings of 10th International Cocoa Research Conference, Santo Damingo, Dominican Rep. May 17-23, 1988, pp. 867 - 871.

[28] O. A. Fagbenro, "Utilization of CPH in low cost diets by the clarias catfish," Clarias Isheriensis: Aquaculture and Fisheries Management, vol. 23, pp. 175 - 182, 1992. View at Google Scholar $\mid$ View at Publisher

[29] D. Adomako, "Processing of cocoa pod husk into animal feed," in Proceedings of the International Conference on Tree Crops, Owerri, Nigeria, March, 1991, pp. $40-43$.

[30] O. Sobamiwa and O. G. Longe, "Utilization of cocoa pod pericarp fractions in broiler chick diets," Animal Feed Science and Technology, vol. 47, pp. 237 - 244, 1994. View at Google Scholar | View at Publisher 
[31] Anon, International cocoa gene bank, trinidad cocoa research unit, bulletin (1). Trinidad: University of W/Indies, St. Augustine, 1989.

[32] L. K. Opeke, Tropical tree crops. Spectrum books limited, 1st ed. Ibadan: Sun Shine House, 1997.

[33] S. S. Abiola and O. O. Tewe, "Chemical evaluation of cocoa by - products," Tropical Agriculture, vol. 68, pp. 335 - 336, 1991. View at Google Scholar

[34] Google Earth, "Geonames geographical database, courtesy of google earth. Traveling luck for Calabar, Cross River State, Nigeria. Time zone, latitude, longitude, elevation and map/satellite image. [Accessed 11/13/2013]," 2012.

[35] E. R. Akpan, J. O. Offem, and A. E. Nya, "Baseline ecological studies of the Great Kwa River, Nigeria 1: Physicochemical studies," African Journal of Environmental Pollution and Health, vol. 1, pp. 83-90, 2002. View at Google Scholar

[36] A. Teguia, H. N. L. Endeley, and A. C. Beynan, "Broiler performance upon dietary substitution of cocoa husks for maize," International Journal of Poultry Science, vol. 3, pp. 779 - 782, 2004. View at Google Scholar $\mid$ View at Publisher

[37] K. O. Bello, D. Eruvbetine, O. A. Fanimo, and B. J. Aina, "Sensible heat balance of egg- type chickens fed fermented and unfermented groundnut husk diets," Nigerian Journal of Animal Production, vol. 39, pp. 74- 85, 2012.

[38] A. A. Odunsi, O. Sobamiwa, and O. G. Longe, "Comparative utilization of alkali - treated and untreated cocoa bean cake in diets of egg type chickens," Tropical Journal of Animal Science, vol. 2, pp. 63 - 68, 1999. View at Google Scholar | View at Publisher

[39] O. Olubamiwa, S. M. Ikyo, B. A. Adebowale, A. B. Omojola, and R. A. Hamzat, "Effect of boiling time on the utilization of cocoa bean shell in laying O. Olubamiwa, S. M. Ikyo, B. A. Adebowale, A. B. Omojola, and R. A. Hamzat, "Effect of boiling time on the utiliza
hen feeds," International Journal of Poultry Science, vol. 5, pp. 1137 - 1139, 2006. View at Google Scholar $\mid$ View at Publisher

[40] A. O. Adeyina, D. F. Apata, A. A. Annongu, O. A. Olatunde, O. I. Alli, and K. M. Okupke, "Performance and physiological response of weaner rabbits fed hot - water treated cocoa bean shell based diets," Research Journal of Animal and Veterinary Sciences, vol. 5, pp. $53-57$, 2010. View at Google Scholar

[41] O. A. Ogunwole, A. Akinfemi, and A. O. Akinsoyinu, "Degradation of crude protein in groundnut cake, guinea grass (Panicum Maximum) and rumen epithelial scraping based diets by West African Dwarf sheep," Nigerian Journal of Animal Production, vol. 38, pp. $106-115,2010$.

[42] A.O. A.C, Official method of analysis, 15th ed. vol. 1. Washington D.C: Association of Official Analytical Chemists, 1990. E. Q. Javier, "Breeding for forage quality. A. S.P.A.C. Food production technology centre," Extension Bulletin, vol. 50, pp. 1 - 29, 1995. V. A. Oyenuga, Nigeria feeds and feeding stuff. Their chemistry and nutritive values. Ibadan: Heinemann Educational Books, 1987. SAS, Statistical analysis system (SAS/TAT) user's guide release 6.o. Cary N, C. USA: Statistical Analysis Systems Institute Inc, 1999. R. G. D. Steel and J. H. Torrie, Principles and procedures of statistics. A biometric approach, 2nd ed. New York, USA: McGraw Hill Book Co. Inc, 1980.

[47] N.R.C, National research council. Nutrient requirements of domestic animals: Nutrient requirement of rabbits, 2nd ed. Washington D.C: National Academy of Sciences, 1984.

[48] D. Fielding, Rabbits. The tropical agriculturist. CTA Netherlands: Macmillan Publishers, 1991

[49] A. O. Aduku, "Tropical feedstuffs nutrient analyses table, A. B. U., Zaria," 1993.

${ }_{50}=\quad$ O. O. Ojebiyi, G. O. Farinu, G. M. Babatunde, and O. O. Morunfolu, "Effect of varying levels of sun dried cassava peel blood meal mixture (3:2) on growth performance and organ characteristics of weaner rabbits," Journal of Animal and Veterinary Advances, vol. 5 , pp. $886-890$, 2006. View at Google Scholar

[51] K. U. Amaefule and M. O. Ironkwe, "Response of weaner rabbits fed graded levels of raw Bambara groundnut (Vigna Subterranean L.) diets," in Proceedings of the 32nd Annual Conference of the Nigerian Society for Animal Production (NSAP), held at the University of Calabar, Nigeria, March 18-21, 2007, pp. $236-239$.

[52] N.R.C, National research council. Nutrient requirements of domestic animals: Nutrient requirement of rabbits, 2nd ed. Washington D.C: National Academy of Sciences, 1977.

[53] A. A. Onifade, O. A. Abu, R. I. Obiyan, and O. T. F. Abanikannda, "Rabbit production in Nigeria: Some aspects of current status and promotional strategies," World Rabbit Science, vol. 7, pp. $51-58,1999$.

[54] F. Lebas, "Nutrient requirements of rabbits," Journal of Applied Rabbit Research, vol. 3, pp. 15 - 20, 1980.

[55] K. A. Champ and D. V. Maurice, "Research review on response of early weaned rabbits to source and level of dietary fibre," Journal of Applied Rabbit Research, vol. 6, pp. 64-67, 1983. View at Google Scholar

[56] P. R. Cheeke, "Rabbit nutrition and feeding: Recent advances and future perspectives," Journal of Applied Rabbit Research, vol. 7, pp. $31-37,1984$. View at Google Scholar

[57] T. A. Omole, A. Adejuyigbe, F. T. Ajayi, and J. B. Fapohunda, "Nutritive value of stylosanthes guinensis and lablab purpureus as sole feed for growing rabbits," African Journal of Biotechnology, vol. 6, pp. 2171 - 2173, 2007. View at Google Scholar $\mid$ View at Publisher

[58] F. Alamowor, V. P. Dzogbefia, E. O. K. Oddoye, and J. D. Oldham, "Enzyme cocktail for enhancing poultry utilization of cocoa pod husk," Scientific Research and Essay, vol. 4, pp. 555 - 559, 2009. View at Google Scholar

[59] B. G. Marcel, K. B. Andre, D. Theodore, and K. C. Seraphin, "Waste and by - products of cocoa in breeding: Research synthesis," International Journal of Agronomy and Agricultural Research, vol. 1, pp. 9 - 19, 2011.

[60] R. A. Hamzat and O. Adeola, "Chemical evaluation of co-products of cocoa and kola as livestock feeding stuffs," Journal of Animal Science Advances, vol. 1, pp. 61 - 68, 2011. View at Google Scholar

[61] M. A. Isika, E. E. Nsa, and P. O. Ozung, "Replacement value of processed cocoa bean meal for groundnut cake in rations for fryer rabbits," Journal of Sustainable Technology, vol. 3, pp. $118-127,2012$.

[62] E. O. Ahaotu, A. Akinfemi, and T. K. O. Obih, "Effects of processed ripe banana peel (Musa Sapientum) as energy source for growing Dutch rabbits," in Proceedings of the 38th Annual Conference of Nigerian Society for Animal Production (NSAP) held at Rivers State University of Science and Technology, Choba, Port Harcourt, Nigeria, March 17-20, 2013, pp. $275-277$.

[63] O. Onyema and G. Iwuala, Effects of processed ripe banana peel meal as energy source for growing Dutch rabbits. Research Project, Imo State Polytechnic, 2011.

[64] J. Alexander, H. C. Andersson, A. Bernhoft, L. Brimer, and B. Cottrill, "Theobromine as undesirable substance in animal feed: Scientific opinion of the panel on contaminants in the food chain," EFSA Journal, vol. 725, pp. 1 - 66, 2008.

[65] FAO, "Food \& agriculture organization. World agriculture: Towards 2015/2030," Summary Report. Rome, Food and Agriculture Organization of the United Nations, 2002.

[66] C. Devender, "The feeding values of by - products from cocoa and coconuts in diets for farm livestock," presented at the Reprint from 1978 International Conference on Cocoa and Coconuts, 1978.

[67] E. J. Day and B. C. Dilworth, "Toxicity of jimson weed seed and cocoa shell meal to broilers," Poultry Science, vol. 63, pp. 466 - 468, 1984. View at Google Scholar | View at Publisher

[68] T. Gidenne, V. Pinheiro, and L. Falcaoe- Cunha, "A comprehensive approach of rabbit digestion: Consequences of a reduction in dietary fibre supply," Livestock Production Science, vol. 64, pp. 225-237, 2000. View at Google Scholar | View at Publisher

[69] N. Nicodemus, R. Carabano, J. Garcia, J. Mendez, and C. De Blas, "Performance response of lactating and growing rabbits to dietary lignin content," Animal Feed Science Technology, vol. 80, pp. 43 - 54, 1999. View at Google Scholar $\mid$ View at Publisher

[70] W. Ndindana, K. Dzama, P. N. B. Ndiweni, S. M. Maswaure, and M. Chimonyo, "Digestibility of high fibre diets and performance of growing Zimbabwean indigenous Mukota pigs and exotic large white pigs fed maize based with graded levels of maize cobs," Animal Feed Science and Technology, vol. 97, pp. $199-208$, 2002. View at Google Scholar $\mid$ View at Publisher

[71] M. L. Kass, P. J. Van Soest, W. G. Pond, B. Lewis, and R. E. McDowell, "Utilization of dietary fibre from alfalfa by growing swine. I: Apparent digestibility of diet components in specific segments of gastro- intestinal tract," Journal of Animal Science, vol. 50, pp. 175 - 191, 1980. View at Google Scholar $\mid$ View at Publisher

[72] F. Meffeja, N. Njifutie, Y. Manjeli, T. Dongmo, J. Tehakounte, and R. B. Fombad, "Digestibilite et influence des rations contenant des niveaux croissants de coques de cacao sur les performances des pores en croissance finition," Cellulose, vol. 17, p. 8, 2006. View at Google Scholar

[73] A. O. Adedire, O. O. Oduguwa, M. O. Edema, O. S. Onifade, and C. F. I. Onwuka, "Performance and nutrient utilization of rabbits fed diets based on crop residues fermented with Rhizopus oligosporus," Nigerian Journal of Animal Production, vol. 39, pp. 114$121,2012$.

[74] T. Gidenne, R. Carabano, J. Garcia, and C. De Blas, "Fibre digestion in nutrition of rabbits. De bias, C. \& Wiseman, J. (Eds.), Pp. 69 - 88. In: Adedire, A. O., Oduguwa, O. O., Edema, M. O., Onifade, O. S. \& Onwuka, C. F. I. (2012).Performance and nutrient 
utilization of rabbits fed diets based on crop residues fermented with Rhizopus oligosporus," Nigerian Journal of Animal Production, vol. 39, pp. 114-121, 1998.

[75] A. M. Aboushour and M. A. Baraket, "Effect of dietary fibre levels on digestibility performance and caecal microbial activity in growing rabbits," World Review in Animal Production, vol. 22, pp. $52-54,1986$.

[76] O. O. Oduguwa, O. O. Sobamiwa, D. Sanni, and A. Y. Akintunde, "Effect of urea treatment on the utilization of cocoa pod husk in rabbit diets," Tropical Journal of Animal Science, vol. 1, pp. 23 - 28, 1999. View at Google Scholar | View at Publisher

[77] A. A. Odunsi and O. G. Longe, "The nutritive value of hot water or cocoa pod ash solution treated cocoa bean cake for broiler chicks," British Poultry Science, vol. 39, pp. 519 - 525, 1998. View at Google Scholar |View at Publisher 
Table-1. Gross composition of experimental diets

\begin{tabular}{|c|c|c|c|c|c|c|c|c|c|c|c|c|}
\hline \multicolumn{5}{|c|}{ Dietary treatments \& levels of RCPHM } & \multicolumn{4}{|c|}{ Dietary treatments \& levels of FCPHM } & \multicolumn{4}{|c|}{ Dietary treatments \& levels of HCPHM } \\
\hline Ingredients & $T_{1}(0 \%)$ & $T_{2}(12.50 \%)$ & $\begin{array}{c}\mathbf{T}_{3} \\
(\mathbf{2 5 . 0 0 \% )}) \\
\end{array}$ & $T_{+}(37.50 \%)$ & $\mathbf{T}_{5}(\mathbf{0 \%})$ & $\begin{array}{c}\mathrm{T}_{6} \\
(12.50 \%) \\
\end{array}$ & $T_{7}(25.00 \%)$ & $\mathrm{T}_{8}(37.50 \%)$ & $T_{9}(0 \%)$ & $\begin{array}{c}T_{10} \\
(12.50 \%) \\
\end{array}$ & $\begin{array}{c}\mathbf{T}_{11} \\
(\mathbf{2 5 . 0 0 \% )} \\
\end{array}$ & $\begin{array}{c}\mathbf{T}_{12} \\
(\mathbf{3 7 . 5 0} \%) \\
\end{array}$ \\
\hline Yellow Maize & 36.00 & 33.00 & 30.00 & 27.00 & 36.00 & 33.00 & 30.00 & 27.00 & 36.00 & 33.00 & 30.00 & 27.00 \\
\hline Soybean $\mathrm{m}$. & 15.70 & 16.00 & 16.00 & 17.00 & 15.70 & 16.00 & 16.00 & 17.00 & 15.70 & 16.00 & 16.00 & 17.00 \\
\hline PKC & 4.00 & 6.00 & 7.00 & 8.00 & 4.00 & 6.00 & 7.00 & 8.00 & 4.00 & 6.00 & 7.00 & 8.00 \\
\hline Wheat offal & 10.00 & 6.25 & 5.50 & 1.00 & 10.00 & 6.25 & 5.50 & 1.00 & 10.00 & 6.25 & 5.50 & 1.00 \\
\hline Rice husk & 27.00 & 18.95 & 9.20 & 2.20 & 27.00 & 18.95 & 9.20 & 2.20 & 27.00 & 18.95 & 9.20 & 2.20 \\
\hline RCPHM & 0.00 & 12.50 & 25.00 & 37.50 & 0.00 & 0.00 & 0.00 & 0.00 & 0.00 & 0.00 & 0.00 & 0.00 \\
\hline FCPHM & 0.00 & 0.00 & 0.00 & 0.00 & 0.00 & 12.50 & 25.00 & 37.50 & 0.00 & 0.00 & 0.00 & 0.00 \\
\hline HCPHM & 0.00 & 0.00 & 0.00 & 0.00 & 0.00 & 0.00 & 0.00 & 0.00 & 0.00 & 12.50 & 25.00 & 37.50 \\
\hline Bone meal & 2.00 & 2.00 & 2.00 & 2.00 & 2.00 & 2.00 & 2.00 & 2.00 & 2.00 & 2.00 & 2.00 & 2.00 \\
\hline Palm oil & 2.50 & 2.50 & 2.50 & 2.50 & 2.50 & 2.50 & 2.50 & 2.50 & 2.50 & 2.50 & 2.50 & 2.50 \\
\hline Methionine & 0.25 & 0.25 & 0.25 & 0.25 & 0.25 & 0.25 & 0.25 & 0.25 & 0.25 & 0.25 & 0.25 & 0.25 \\
\hline Lysine & 0.25 & 0.25 & 0.25 & 0.25 & 0.25 & 0.25 & 0.25 & 0.25 & 0.25 & 0.25 & 0.25 & 0.25 \\
\hline Salt $(\mathrm{NaCl})$ & 0.10 & 0.10 & 0.10 & 0.10 & 0.10 & 0.10 & 0.10 & 0.10 & 0.10 & 0.10 & 0.10 & 0.10 \\
\hline Premix & 0.20 & 0.20 & 0.20 & 0.20 & 0.20 & 0.20 & 0.20 & 0.20 & 0.20 & 0.20 & 0.20 & 0.20 \\
\hline Total & 100.00 & 100.00 & 100.00 & 100.00 & 100.00 & 100.00 & 100.00 & 100.00 & 100.00 & 100.00 & 100.00 & 100.00 \\
\hline \multicolumn{13}{|c|}{ Calculated analysis : } \\
\hline$\% \mathrm{CP}$ & 16.00 & 16.04 & 16.32 & 16.61 & 16.00 & 16.04 & 16.32 & 16.61 & 16.00 & 16.04 & 16.32 & 16.61 \\
\hline$\% \mathrm{CF}$ & 10.00 & 11.65 & 13.54 & 15.87 & 10.00 & 11.65 & 13.54 & 15.87 & 10.00 & 11.65 & 13.54 & 15.87 \\
\hline ME (Kcal/Kg) & $2,500.75$ & $2,505.80$ & $2,524.85$ & $2,536.90$ & $2,500.75$ & $2,505.80$ & $2,524.85$ & $2,536.90$ & $2,500.75$ & $2,505.80$ & $2,524.85$ & $2,536.90$ \\
\hline
\end{tabular}

Note: Gross Composition of Bio -Super Premix per Ko:

Vitamin A -1,5000,000IU; Vitamin D3 - 300,000IU; Vitamin E - 400mg; Vitamin K3 - 100mg.

Vitamin B2 - 400mg; Vitamin B12 - 2,000mg; Nicotinamide - 2,000mg; Calcium D - Panto-

thenate - 800mg; Choline Chloride - 40,000mg; Ferrous sulphate - 2,000mg; Manganese sulphate - 5,000mg; Copper sulphate - 80mg; Zinc oxide - 3,00omg; Cobalt sulphate - 10mg; Potassium iodide - 120mg;

The premix was manufactured by

.

CP - Crude Protei

Theob: Theobromine content - calculated based on standard method proposed by Odunsi and Longe [77].

ME - Metabolizable Energy 
Table-2. Proximate composition (determined analysis) of experimental diets

\begin{tabular}{|c|c|c|c|c|c|c|c|c|c|c|c|c|c|}
\hline \multirow[b]{2}{*}{ Parameter } & \multirow[b]{2}{*}{$T_{1}$} & \multicolumn{2}{|c|}{ RCPHM DIETS } & \multirow[b]{2}{*}{$\mathbf{T}_{4}$} & \multirow[b]{2}{*}{$\mathbf{T}_{5}$} & \multicolumn{2}{|c|}{ FCPHM DIETS } & \multirow[b]{2}{*}{$\mathbf{T}_{8}$} & \multirow[b]{2}{*}{$T_{9}$} & \multicolumn{2}{|c|}{ HCPHM DIETS } & \multirow[b]{2}{*}{$T_{12}$} & \multirow[b]{2}{*}{ 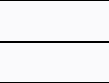 } \\
\hline & & $T_{2}$ & $\mathbf{T}_{s}$ & & & $\mathbf{T}_{6}$ & $\mathbf{T}_{7}$ & & & $T_{10}$ & $\mathbf{T}_{11}$ & & \\
\hline$(\%)$ & $0 \%$ & $12.50 \%$ & $25.00 \%$ & $37.50 \%$ & $0 \%$ & $12.50 \%$ & $25.00 \%$ & $37.50 \%$ & $0 \%$ & $12.50 \%$ & $25.00 \%$ & $37.50 \%$ & S.E.M \\
\hline Dry matter & $88.28^{\mathrm{c}}$ & $89.03^{\mathrm{b}}$ & $92.64^{\mathrm{a}}$ & $87.10^{\mathrm{f}}$ & $88.28^{\mathrm{c}}$ & $88.70^{\mathrm{b}}$ & $88.75^{\mathrm{b}}$ & $88.32^{\mathrm{b}}$ & $88.28^{\mathrm{c}}$ & $87.32^{\mathrm{c}}$ & $87.99^{\mathrm{d}}$ & $88.61^{\mathrm{b}}$ & 0.05 \\
\hline Crude protein & $18.30^{\mathrm{b}}$ & $17.86^{\mathrm{d}}$ & $18.08^{c}$ & $14.04^{\mathrm{f}}$ & $18.30^{\mathrm{b}}$ & $17.80^{\mathrm{d}}$ & $15.89^{\mathrm{e}}$ & $17.45^{\mathrm{c}}$ & $18.30^{\mathrm{b}}$ & $14.16^{f}$ & $15.56^{\mathrm{e}}$ & $18.73^{\mathrm{a}}$ & 0.009 \\
\hline Crude fibre & $14.13^{\mathrm{f}}$ & $18.55^{\mathrm{cd}}$ & $20.03^{\mathrm{e}}$ & $23.53^{\mathrm{b}}$ & $14.13^{\mathrm{f}}$ & $14.67^{\mathrm{f}}$ & $13.38^{\mathrm{f}}$ & $26.37^{\mathrm{a}}$ & $14.13^{\mathrm{f}}$ & $22.66^{\mathrm{c}}$ & $21.46^{\mathrm{d}}$ & $23.08^{\mathrm{b}}$ & 0.007 \\
\hline $\mathrm{EE}$ & $10.53^{\mathrm{e}}$ & $12.17^{\mathrm{b}}$ & $11.57^{\mathrm{c}}$ & $10.63^{\mathrm{e}}$ & 10.53 & $11.36^{\mathrm{c}}$ & $14.81^{\mathrm{a}}$ & $10.98^{\mathrm{d}}$ & $10.53^{\mathrm{e}}$ & $9.91^{\mathrm{f}}$ & $11.13^{\mathrm{c}}$ & $10.95^{\mathrm{d}}$ & 0.009 \\
\hline Ash & $10.21^{\mathrm{e}}$ & $10.94^{\mathrm{a}}$ & $8.36^{\mathrm{d}}$ & $9.31^{\mathrm{d}}$ & $10.21^{\mathrm{e}}$ & $7.60^{\mathrm{f}}$ & $8.48^{\mathrm{d}}$ & $10.82^{\mathrm{b}}$ & $10.21^{\mathrm{e}}$ & $10.45^{\mathrm{c}}$ & $10.38^{\mathrm{d}}$ & $10.38^{\mathrm{d}}$ & 0.006 \\
\hline NFE & $46.83^{\mathrm{b}}$ & $40.48^{\mathrm{d}}$ & $41.96^{\mathrm{c}}$ & $42.49^{\mathrm{c}}$ & $46.83^{\mathrm{b}}$ & $48.57^{\mathrm{a}}$ & $47.44^{\mathrm{b}}$ & $34.38^{\mathrm{e}}$ & $46.83^{\mathrm{b}}$ & $42.82^{\mathrm{c}}$ & $41.47^{\mathrm{d}}$ & $36.86^{\mathrm{e}}$ & 0.09 \\
\hline
\end{tabular}

Note: a, b,c.c.fi Means on the same row with different superscripts are significantly different $(\mathrm{P}<0.05)$

All Mean values are obtained from Triplicate samples per treatment/diet

RCPHM: Raw Cocoa Pod Husk Meal

HCPHM: Hot -water treated Cocoa Pod Husk Mes

EE: Ether extract

S. M. Standard Fror of Mean

Table-3. Proximate composition and fibre fractions of raw and processed cocoa pod husk meal

\begin{tabular}{|c|c|c|c|c|}
\hline Parameter & & Test ingredient & & \\
\hline$(\%)$ & RCPHM & \begin{tabular}{l|l} 
FCPHM \\
\end{tabular} & HCPHM & S.E.M \\
\hline Dry Matter & $94.60^{\mathrm{a}}$ & $84.40^{\mathrm{b}}$ & $85.28^{\mathrm{b}}$ & 3.27 \\
\hline Crude Protein & $9.37^{\mathrm{a}}$ & $7.70^{\mathrm{b}}$ & $8.94^{\mathrm{a}}$ & 0.50 \\
\hline Crude Fibre & $61.80^{\mathrm{a}}$ & $57.42^{\mathrm{b}}$ & $53.37^{\mathrm{c}}$ & 2.44 \\
\hline Ether extract & $8.83^{\mathrm{b}}$ & $9.52^{\mathrm{b}}$ & $11.68^{\mathrm{a}}$ & 0.86 \\
\hline Ash & $9.30^{\mathrm{b}}$ & $10.80^{\mathrm{a}}$ & $10.85^{\mathrm{a}}$ & 0.51 \\
\hline Nitrogen Free Extract & $10.70^{\mathrm{b}}$ & $14.56^{\mathrm{a}}$ & $15.16^{\mathrm{a}}$ & 1.40 \\
\hline $\mathrm{ADF}$ & $68.64^{\mathrm{b}}$ & $73.09^{\mathrm{a}}$ & $64.60^{\mathrm{c}}$ & 2.46 \\
\hline NDF & $75.08^{\mathrm{b}}$ & $79.45^{\mathrm{a}}$ & $71.09^{\mathrm{c}}$ & 2.42 \\
\hline TDN & 1.52 & 1.28 & 1.43 & 0.07 \\
\hline
\end{tabular}

ntly different $(\mathrm{P}<0.05)$

Note: a,b,c means on the same row with different superscripts are signiliet

RCPHM- Raw Cocoa Pod Husk Meal

FCPHM - Fermented Cocoa Pod Husk Meal

HCPHM - Hot - water treated Cocoa Pod Husk Meal

CF: Crude proten

EE: Ether extract $\quad$ S.E.M: Standard Error of Mean

NFE: Nitrogen free extract
ADF: Acid detergent fibre 
Table-4. Pre-pubertal growth performance characteristics of weaned rabbits fed cocoa pod husk meal- based diets

\begin{tabular}{|c|c|c|c|c|c|c|c|c|c|c|c|c|c|}
\hline \multirow[b]{2}{*}{ Performance trait } & \multirow[b]{2}{*}{$T_{1}$} & \multicolumn{2}{|c|}{ RCPHM DIETS } & \multirow[b]{2}{*}{$\mathbf{T}_{4}$} & \multirow[b]{2}{*}{$\mathbf{T}_{5}$} & \multicolumn{2}{|c|}{ FCPHM DIETS } & \multirow[b]{2}{*}{$\mathbf{T}_{8}$} & \multirow[b]{2}{*}{$T_{9}$} & \multicolumn{2}{|c|}{ HCPHM DIETS } & \multirow[b]{2}{*}{$T_{12}$} & \multirow[b]{3}{*}{ S.E.M } \\
\hline & & $\mathbf{T}_{2}$ & $\mathbf{T}_{3}$ & & & $\mathbf{T}_{6}$ & $\mathbf{T}_{7}$ & & & $\mathbf{T}_{10}$ & $\mathbf{T}_{11}$ & & \\
\hline & $0 \%$ & $12.50 \%$ & $25.00 \%$ & $37.50 \%$ & $0 \%$ & $12.50 \%$ & $25.00 \%$ & $37.50 \%$ & $0 \%$ & $12.50 \%$ & $25.00 \%$ & $37.50 \%$ & \\
\hline Initial Wt. (g/rabbit) & 602.00 & 610.00 & 608.00 & 605.00 & 605.00 & 610.00 & 602.50 & 612.50 & 600.00 & 612.00 & 600.00 & 610.00 & 1.32 \\
\hline Final Wt. (g/rabbit) & $1650.00^{\mathrm{a}}$ & $1300.00^{\mathrm{b}}$ & $1480.00^{\mathrm{ab}}$ & $1162.5 \mathrm{O}^{\mathrm{b}}$ & $1512.50^{\mathrm{ab}}$ & $1266.67^{\mathrm{b}}$ & $1475.00^{\mathrm{ab}}$ & $1183.33^{\mathrm{b}}$ & $1310.00^{\mathrm{b}}$ & $1250.00^{\mathrm{b}}$ & $993.33^{\mathrm{c}}$ & $1000.00^{c}$ & 58.52 \\
\hline Wkly. Feed Intake (g/rbt.) & 468.61 & 437.70 & 414.91 & 370.86 & 465.30 & 483.54 & 439.63 & 439.26 & 450.41 & 490.99 & 496.33 & 498.12 & 10.83 \\
\hline $\mathrm{ADF}$ (g/rabbit/day) & $66.94^{\mathrm{b}}$ & $62.56^{\mathrm{c}}$ & $59.27^{\mathrm{d}}$ & $52.98^{\mathrm{d}}$ & $66.47^{\mathrm{b}}$ & $69.08^{\mathrm{b}}$ & $62.80^{\mathrm{c}}$ & $62.75^{\mathrm{c}}$ & $64.34^{\mathrm{bc}}$ & $70.14^{\mathrm{a}}$ & $70.90^{\mathrm{a}}$ & $71.16^{\mathrm{a}}$ & 3.87 \\
\hline Total Wt. Gain (g/rbt.) & $1048.00^{\mathrm{a}}$ & $690.00^{\mathrm{c}}$ & $872.00^{\mathrm{b}}$ & $557.50^{\mathrm{d}}$ & $907.50^{\mathrm{b}}$ & $656.67^{\mathrm{c}}$ & $872.50^{\mathrm{b}}$ & $570.83^{\mathrm{d}}$ & $710.00^{\mathrm{bc}}$ & $638.00^{\mathrm{c}}$ & $393.33^{\mathrm{e}}$ & $390.00^{\mathrm{e}}$ & 26.85 \\
\hline Wkly. Wt. Gain (g/rbt.) & 116.44 & 76.67 & 96.89 & 61.94 & 100.83 & 72.96 & 96.94 & 63.42 & 78.89 & 70.89 & 43.70 & 43.33 & 24.13 \\
\hline ADG (g/rabbit/day) & 16.63 & 10.95 & 13.84 & 8.85 & 14.40 & 10.42 & 13.85 & 9.06 & 11.27 & 10.13 & 6.24 & 6.19 & 0.93 \\
\hline \begin{tabular}{|l|l} 
FCR & \\
\end{tabular} & 4.03 & 5.71 & 4.28 & 5.99 & 4.62 & 6.63 & 4.53 & 6.93 & 5.71 & 6.92 & 11.36 & 11.50 & 0.72 \\
\hline Mortality (\%) & $20.00 *$ & 00.00 & 0.00 & 00.00 & 00.00 & 0.00 & 00.00 & $20.00 *$ & 0.00 & 00.00 & 00.00 & 00.00 & 2.61 \\
\hline
\end{tabular}

Mortality (\%)

\begin{tabular}{l|l}
5.71 & 4.28 \\
00.00 & 0.00 \\
\hline
\end{tabular}

RCPHM: Raw Cocoa Pod Husk Meal

FCPPM: Fermented Cocoa Pod Husk Meal

Why Wusk Meal

ADF: Average Daily Feed Intake

FCR: Feed Conversion Ratio

AD: Average Daily Feed In

S.E.M.: Standard Error of mean

* Mortality due to soldier ants invasion

Table-5. Nutrient digestibilty co - efficients of rabbits fed diets containing cocoa pod husk meal (CPHM)

\begin{tabular}{|c|c|c|c|c|c|c|c|c|c|c|c|c|c|}
\hline Parameter & & RCPHM & & & & & FCPHM & & & НСРНМ & & & \\
\hline$(\%)$ & $T_{1}$ & $\mathrm{~T}_{2}$ & $\mathbf{T}_{s}$ & $\mathbf{T}_{4}$ & $\mathbf{T}_{5}$ & $\mathbf{T}_{6}$ & $\mathbf{T}_{7}$ & $\mathbf{T}_{8}$ & $\mathbf{T}_{9}$ & $T_{10}$ & $\mathbf{T}_{11}$ & $\mathbf{T}_{12}$ & \\
\hline & $0 \%$ & $12.50 \%$ & $25.00 \%$ & $37.50 \%$ & $0 \%$ & $12.50 \%$ & $25.00 \%$ & $37.50 \%$ & $0 \%$ & $12.50 \%$ & $25.00 \%$ & $37.50 \%$ & S.E.M \\
\hline Dry matter & 96.32 & 96.43 & 95.41 & 96.43 & 96.35 & 95.58 & 96.42 & 96.33 & 96.34 & 96.43 & 96.27 & 96.31 & 0.09 \\
\hline Crude protein & 78.14 & 77.88 & 77.21 & 75.07 & 76.78 & 78.54 & 72.18 & 78.11 & 77.32 & 73.31 & 74.42 & 77.74 & 0.61 \\
\hline Crude fibre & 77.92 & 78.44 & 75.04 & 74.50 & 76.79 & 71.03 & 61.14 & 76.68 & 77.42 & 85.97 & 80.80 & 82.19 & 1.78 \\
\hline Ether extract & 71.51 & 83.57 & 78.39 & 76.48 & 76.26 & 82.39 & 79.74 & 77.23 & 81.01 & 74.77 & 82.03 & 81.74 & 1.05 \\
\hline Ash & $79.82^{\mathrm{a}}$ & $63.25^{\mathrm{b}}$ & $48.44^{\mathrm{c}}$ & $64.23^{\mathrm{b}}$ & $79.82^{\mathrm{a}}$ & $66.05^{\mathrm{b}}$ & $56.84^{\mathrm{c}}$ & $72.64^{\mathrm{b}}$ & $79.82^{\mathrm{a}}$ & $63.35^{\mathrm{b}}$ & $75.92^{\mathrm{ab}}$ & $83.33^{\mathrm{a}}$ & 3.12 \\
\hline Nitrogen free extract & $73.99^{\mathrm{a}}$ & $65.49^{\mathrm{b}}$ & $62.04^{\mathrm{b}}$ & $63.92^{\mathrm{b}}$ & $74.18^{\mathrm{a}}$ & $73.96^{\mathrm{a}}$ & $65.68^{\mathrm{b}}$ & $55.12^{\mathrm{c}}$ & $75.66^{\mathrm{a}}$ & $68.97^{\mathrm{b}}$ & $69.62^{\mathrm{b}}$ & $67.42^{\mathrm{b}}$ & 1.75 \\
\hline
\end{tabular}

Note: a,b,c, Means on the same row with different superscripts are significantly different $(\mathrm{P}<0.05)$

FCPHM: Fermented Cocoa Pod Mual

HCPHM:Hot -water treated Cocoa Pod Husk Meal

S.E.M.: Standard Error of mean

Asian Online Journal Publishing Group is not responsible or answerable for any loss, damage or liability, etc. caused in relation to/arising out of the use of the content. Any queries should be directed to the corresponding author of the article. 